\title{
The Impact of Creative Problem Solving Strategy Vs Learning Cycle Model And Cognitive Style on The Understanding of Comparison Concept
}

\author{
Muhammad Ainul Fudo'il ${ }^{1}$, I Nyoman Sudana Degeng ${ }^{2}$, Nurmida Catherine Sitompul ${ }^{3}$ \\ ${ }^{1,3}$ Educational Technology, Postgraduate Program of PGRI Adi Buana University Surabaya \\ ${ }^{2}$ Educational Technology, Postgraduate Program of State University of Malang
}

\section{Edcomtech}

\section{Jurnal Kajian}

Teknologi Pendidikan

Volume 4, No 1, April 2019

74-82

Submitted 09-09-2018

Accepted 03-15-2019

\section{Corresponding Author}

Muhammad Ainul Fudo'il

eldoenk@gmail.com

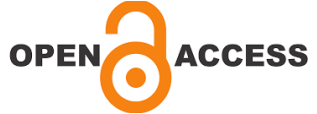

\begin{abstract}
Abstrak
Penelitian ini bertujuan untuk menguji perbedaan dalam pemahaman konsep perbandingan dalam kelompok siswa yang mengambil pembelajaran matematika realistis melalui strategi Creative Problem Solving (CPS) dan Learning Cycle Model (LCM). Ini juga menguji perbedaan dalam pemahaman konsep perbandingan antara kelompok siswa yang memiliki Gaya Kognitif Field Independen (FI) dan Field Dependent (FD). Terakhir, ini menguji apakah ada interaksi antara strategi pembelajaran dan Gaya Kognitif terhadap pemahaman siswa tentang konsep perbandingan. Penelitian ini menggunakan desain penelitian eksperimen semu, dengan desain faktorial desain pretes-posttest nonequivalent $2 \times 2$. Analisis data menggunakan ANOVA dua arah dengan memanfaatkan perangkat lunak statistik SPSS versi 22 untuk windows. Subjek penelitian ini adalah 53 siswa kelas tujuh sekolah menengah Islam (MTs) Azzainabiyah Pramian Sampang Madura, yang terdiri dari 2 kelas (kelas eksperimen dan kelas kontrol) dengan tugas non-acak. Instrumen yang digunakan dalam penelitian ini adalah tes Gaya Kognitif yang disebut GEFT (Group Embedded Figure Test) dan tes hasil belajar. Hasil penelitian ini menunjukkan bahwa tidak ada perbedaan dalam pemahaman konsep perbandingan dalam kelompok siswa yang mengambil pembelajaran matematika realistis melalui strategi CPS dan LCM. Ada perbedaan dalam pemahaman konsep perbandingan antara kelompok siswa yang memiliki gaya kognitif FI dan FD. Tidak ada interaksi antara strategi pembelajaran dengan gaya kognitif yang dimiliki oleh siswa terhadap pemahaman konsep perbandingan.
\end{abstract}

Keyword: Matematika Realistis, Pemecahan Masalah Kreatif, Model Siklus Belajar, Gaya Kognitif

\begin{abstract}
This study aims to examine the differences in the understanding of the comparison concept in groups of students who take realistic mathematics learning through the Creative Problem Solving (CPS) and Learning Cycle Model (LCM) strategies. It also examines the differences in the understanding of comparison concept between groups of students who have Field Independent (FI) and Field Dependent (FD) Cognitive Style. Lastly, it examines whether there is an interaction between learning strategies and Cognitive Style towards the students' understanding of the concept of comparison. This study uses quasi-experimental research design, with $2 \times 2$ factorial design pretestposttest nonequivalent control group design. Data analysis uses two-way ANOVA by utilizing SPSS statistical software version 22 for windows. The subjects of this study were 53 seventh-grade students of Islamic junior high school (MTs) Azzainabiyah Pramian Sampang Madura, consisting of 2 classes (experimental class and control class) with nonrandom assignment. The instrument used in this study is the Cognitive Style test called GEFT (Group Embedded Figure Test) and learning outcomes test. The results of this study indicate that there is no difference in the understanding of the concept of comparison in groups of students who take realistic mathematics learning through CPS and LCM strategies. There is a difference in the understanding of the concept of comparison between groups of students who have FI and FD cognitive style. There is no interaction between the strategy of learning with the cognitive style possessed by students towards the understanding of the concept of comparison.
\end{abstract}

Kata kunci: Realistic Mathematic, Creative Problem Solving, Learning Cycle Model, Cognitive Style 


\section{INTRODUCTION}

The ability of students' mindset in accepting material is different, especially in understanding mathematical material. Various opinions of mathematical understanding emerged, some said that mathematics was a symbolic language, a study of numbers (exact) and some even said that mathematics was deductive, axiomatic and accurate. According to Soejadi (in Heruman, 2007: 1) said that mathematics has abstract objects, be based on agreement and deductive mindset. It affects the students in the understanding process. Students are not able to understand the material due to incomprehension in the previous material so that the curriculum is needed to overcome these problems involving the concept map of the lesson. As Degeng (2008) said that curriculum and modules as development products are equipped with practical instructions as a part that is not separated and complementary to the teaching materials of the module, also including the approaches and strategies/ teaching techniques and methods used so that learning objectives can be achieved well.

Basically, students have tried to learn as much as possible, but in reality, the effectiveness of learning activity is lacking. This statement is in accordance with the opinion of Sudirman et al. (1992: 99-100), the lack of active students in effective learning can be expressed in the following forms: (1) student learning outcomes, in general, is only to the level of mastery. It is the lowest form of learning. (2) learning resources used are generally limited to the teacher (explanatory notes from the teacher) and one or two reading books, meaning that the learning resources used in learning are very limited. (3) teachers do not stimulate student's learning activities optimally.

The conditions of teaching and learning activities above can change if the teacher amends the learning system delivered by using a learning model that can stimulate the activity of students in learning and get the expected learning outcomes. According to the study of Sutinah et al. (2015), a learning model becomes a very crucial thing in the learning process and learning outcomes. Degeng
(2013: 39) mentioned that learning objectives essentially refer to the expected learning outcomes. As expected learning outcomes, it means that the learning objectives are set first and then all learning efforts are directed towards achieving those objectives.

Sitompul (2012) said that the strategy of delivering learning content is a component of method variables to carry out the learning process. Thus the use of learning models by setting the cognitive style of students becomes alternative support for the success of the applied learning model. Degeng (1989: 128) stated that the cognitive structures are defined as organizational structures that exist in a person's memory that integrate separate knowledge elements into a conceptual unit.

As we know, the field of study of learning science is centered on efforts to improve the quality of learning. This effort is focused on improvements to the application of the learning process, or variables to the learning method. According to Degeng (2013: 13-14), the learning method variables are further classified into three types, namely: (1) Organizational Strategy, (2) Delivery Strategy, and (3) Management Strategy. In a teaching and learning process, there will be a result called learning outcomes. Especially learning mathematics, students experience learning difficulties not only when learning takes place but also after experiencing learning because students are only able to follow the explanation of the concepts obtained from the teacher's explanation. Whereas in understanding mathematical material, students need to understand the concepts and their contents as well as ways of solving them. As stated by Mukhlason etal. (2015), the conceptual approach to learning strategies makes it easy for students to understand and improve memory in the subject matter being studied.

From the above opinion about the learning model, it can be concluded that the application of strategies and learning models is said to be successful when there are communication and direct involvement between teachers and students in the teaching and learning process. This is in accordance with John, 1967 (in Silberman, Melvin. 1996: 5) who said that learning will be better if students are asked to do the following things: reveal information 
in their own language, provide examples, get to know them in various situations and conditions, observe the relationship between one fact or idea with another, use it in various ways, estimate some of the consequences, reveal the opponent or vice versa. Degeng (2011) suggests that a learner is a subject that determines self-freedom in learning, in other words, learning control is fully held by people who learn.

Based on the observations on the students in the Islamic Junior High School (MTs) Azzainabiyah Pramian Sampang Madura, students only sit and listen to the explanation of mathematical material from the teacher through lectures, writing and textbooks. Students are rarely involved directly in teaching and learning activities in the classroom. Thus, students experience difficulties in solving math problems given by the teacher, while the best way to deliver mathematics is to bring the value of abstractness into reality in life.

Hadi (2017: 8) stated that Realistic Mathematics Education (RME) is a promising approach in learning mathematics. Various references reported that RME has the potential to improve students' mathematical understanding. In accordance with the findings of Soviawati (2011), mathematics learning using the RME approach not only facilitates students to master the understanding of subject matter concepts, but students can remember well from what they have obtained, which ultimately leads to increased student learning outcomes. Whereas according to Soedjadi (in Haji, 2005: 34), RME is essentially an approach in mathematics learning that uses realistic environment that is understood by students to facilitate the learning process of mathematics so that it can achieve the goals of mathematics education better than in the past time. The role of a teacher in the application of RME is very important.

With the problems found above, it needs to be addressed immediately. In this case, the study applies RME by using CPS and LCM learning model strategies that are related to students' cognitive styles (FI and FD) to the results of understanding the concept of mathematics comparison material of seventh graders in the Islamic junior high school
(MTs). The reason to use the CPS and LCM learning models in this study is because in the learning model activities, students were required to carry out activities such as finding mathematical problems and solving them, exploring by interfering with the information needed, communicating in the form of opinions, then weighing and accepting ideas or drawing conclusions and an introduction to the concepts and their application.

According to Forgaty (1997: 3), teaching and learning activity starts with an unstructured problem - something that is chaotic. Problem-solving Method is not only a method of teaching but also a method of thinking. Because in using the problem-solving method, it can utilize other methods starting with finding data to draw conclusions. This is similar to what was stated by Madya (2012: 10), based on his findings using descriptive analysis and MANOVA analysis, the findings explained that the score of learning achievement in chemistry subject and student's self-concept could increase if taught by problem-based learning (PBL) model rather than learning model of exploration, elaboration and confirmation. It is due to the way the presentation of lesson material is made by the problem as the starting point of the discussion to be analyzed and synthesized to find a solution or answer by students (Sudirman et al., 1992: 146). According to Hisham Z et al. (2008: 177), problem-solving strategies could help students think of several alternatives to solve problems and this strategy is suitable for material that contains problem-solving with various alternatives such as mathematics, statistics, composition, policy analysis, medicine, law and counseling.

Learning Cycle Model (LCM) is a constructivist learning model developed by Professor Robert Karplus from the University of California, Berkeley in the 1970s. This model was first used in a Basic Science program called the Science Curriculum Improvement Study. Karplus identifies three phases used in the LCM, namely preliminary exploration, invention and discovery. Charles Barman and Marvin Tolman use the terms exploration, concept introduction, and concept application (Dasna, 2004: 24). According to Widodo et al. (2010: 145), LCM 
consists of three stages, namely Exploration, Invention, and Discovery. The usage of this model is suitable to be applied to the learning of mathematics of comparison chapter. One of the advantages of LCM according to Shiomin (2014) is increasing learning motivation because learners are actively involved in the learning process. Destisari N. et al. (2016) supported the LCM by stating that the implementation of LCM on material regarding the relationship between the nature of materials and their uses can significantly improve students' science process skills.

\section{Cognitive Style}

As explained above, the learning outcomes are closely related to student characteristics and the quality of learning. One of the characteristics of students is Cognitive Style, which is the students' characteristic in learning, starting from the way of receiving information, managing information, and how to respond to information related to the learning environment. According to Gagne (1977a) and also Rigney (1978) in Degeng, (2013: 84), they opined that Cognitive Style strategies are content-free skills that can be used by someone to facilitate the acquisition of knowledge (learning skills), or to facilitate the organization and disclosure of knowledge that has been learned (remembering skills). Whereas according to Sternberg and Elena (1997: 701), Cognitive Style is a bridge between intelligence and personality.

Cognitive style of students used to help this research is Cognitive style based on differences in psychological aspects of students consisting of Field Independent (FI) and Field Dependent (FD). To find out the Cognitive Style possessed by students, learning psychologists develop a Cognitive Style measure. Among the so-called GEFT (Group Embedded Figure Test), this test can distinguish between students with the FI Cognitive Style and students with FD Cognitive Style.

\section{METHOD}

\section{Design and Variables}

This study uses a quasi-experimental research design. Santoso (2005: 32) said that if the three principles of experimental research (replication, randomization, control) were attempted to be fulfilled but it had not yet achieved perfection. Thus it is called a quasi experimental study. The experimental design can be seen in Table 1 below.

Table 1. Factorial Design ( $2 \times 2)$

\begin{tabular}{|c|c|c|}
\hline $\begin{array}{c}\text { COGNITIVE } \\
\text { STYLE }\end{array}$ & \multicolumn{2}{|c|}{ LEARNING STRATEGY } \\
\hline & CPS $\left(X_{1}\right)$ & LCM $\left(X_{2}\right)$ \\
\hline FI & FI, CPS & FI, LCM \\
\hline FD & FD, CPS & FD, LCM \\
\hline
\end{tabular}

\section{Research Subjects}

The subjects in this study were all seventhgrade students in Islamic junior high school (MTs) Azzainabiyah 2017/2018 which amounted 53 children with subject taking not randomized (non random assignment), but based on existing classes because the situation did not allow to change the composition of students in the class that had been determined and experience teaching and learning activities until even semester. As for the details of the number of samples based on the research treatment are in Table 2.

Table 2. Distribution of Research Subjects Based on Treatment Groups, Learning Strategies and Cognitive Styles

\begin{tabular}{|c|c|c|}
\hline $\begin{array}{c}\text { COGNITIVE } \\
\text { STYLE }\end{array}$ & \multicolumn{2}{|c|}{ LEARNING STRATEGY } \\
\hline & CPS $\left(X_{1}\right)$ & LCM $\left(X_{2}\right)$ \\
\hline FI & 12 & 12 \\
\hline FD & 14 & 15 \\
\hline TOTAL & 26 & 27 \\
\hline
\end{tabular}

\section{Research Variables}

This study uses three research variables, namely: 1) Independent Variables consisting of Learning Strategies, namely CPS and LCM. 2) Moderating Variableswhich consist of CognitiveStyle possessed by students, namely FI and FD. 3) Dependent Variables, namely students' understanding of the concepts of mathematics in comparison chapter for seventh-grade students.

\section{Research Treatment}

This study was grouped into two groups, namely the control group given realistic 
mathematics learning with CPS strategy and the experimental group given realistic mathematics learning with the LCM strategy.

Before the implementation of the learning treatment, the two groups who were the subjects of the study were given a GEFT test to find out and identify the cognitive styles possessed by the research subjects as well as be given initial tests/pretests to determine the initial abilities of the two groups.

Research Instrument

The research instruments used in this study consisted of (1) Tests (Pretest \& Posttest), used to measure student learning outcomes and arranged by the researchers themselves. Pretest and posttest are arranged in two parts, namely the first part to measure learning outcomes remembering the concept-procedure and the second part to measure learning outcomes using concept-procedure. The items in the first part are multiple choice, while in the second part they are problem-solving. (2) Cognitive Style Test used to measure and determine the learning characteristics of students with the cognitive style of FI and FD. The Cognitive Style Instrument of this study was developed by Witkin, et al. (1976), and adapted by Degeng (1989), namely the Cognitive Style Instrument called the Embedded Figures Group Test (GEFT). Some things need to be considered in using GEFT instruments, including (1) this test begins with an exercise before starting, so the test takers can do this test properly and correctly. (2) the time needed to do this test is twelve minutes. (3) this test is easy to administer, not so difficult in determining the test result. (4) this test is valid and reliable because it has undergone a lot of testing. (5) in the assessment, a score of 0 will be given if the answer is wrong or does not answer, and score 1 if the answer is correct. (6) from the results of the assessment, it will find out students who have learning characteristics with the FI Cognitive Style and FD Cognitive Style.

\section{RESULTS AND DISCUSSION Descriptive Analysis Results}

Data description of student learning outcomes based on the type of learning strategy on understanding the concept of comparison in the experimental group (CPS learning) and the control group (LCM learning) did not show any difference between the two.

Data description of learning outcomes based on the type of cognitive style students have on understanding the concept of comparison shows that there is a difference between the two ( $F I$ and FD). It shows that the students with FI cognitive style have better learning outcomes than students with FD cognitive style.

Data description from learning outcomes based on the interaction of two variables states that there is no interactive influence between learning strategies and cognitive styles on the understanding of comparison concept.

Results of Statistical Analysis

The calculation of statistical analysis using two-way ANOVA $(2 \times 2)$, Table 3 shows the results of analysis of two-way ANOVA test.

\begin{tabular}{|c|c|c|c|c|c|}
\hline \multicolumn{6}{|c|}{$\begin{array}{l}\text { Table 3. The Analysis Results of } \\
\text { ANOVA Test } \\
\text { Tests of Between-Subjects Effects }\end{array}$} \\
\hline Dependent Variable: & POSTIEST & & & & \\
\hline Sourte & $\begin{array}{l}\text { Trpe II Sum } \\
\text { of Squares }\end{array}$ & di & Mean Square & $\mathrm{F}$ & Sig. \\
\hline Corrected Modal & $680.547^{3}$ & 3 & 226.849 & 2.768 & .052 \\
\hline Intercept & 230127.753 & 1 & 230127.753 & 2808.163 & .000 \\
\hline METODE & 13.503 & 1 & 13.503 & .165 & .687 \\
\hline KOONITF & 540.805 & 1 & 540.805 & 6.599 & .013 \\
\hline METODE^ KOGNTIF & 106.430 & 1 & 106.430 & 1.299 & .260 \\
\hline Error & 4015.529 & 49 & 81.950 & & \\
\hline Total & 234641.000 & 53 & & & \\
\hline Corrected Total & 4696.075 & 52 & & & \\
\hline
\end{tabular}

Based on the results of the analysis of twoway ANOVA test in table 3 , it can answer the proposed research hypothesis, including:

Hypothesis 1, For the first hypothesis, $\mathrm{HO}$ is accepted and $\mathrm{H} 1$ is rejected at a significance level of 0.687 ( $P \geq 0.05 / 5 \%)$, so it found that "there is no difference in understanding the concept of comparison between realistic mathematics learning through CPS and LCM learning strategies."

Hypothesis 2, For the second hypothesis, $\mathrm{HO}$ is rejected and $\mathrm{H} 1$ is accepted at the significance level of 0.013 ( $\mathrm{P} \leq 0.05 / 5 \%$ ). Thus, it found that "there is a difference in understanding the concept of comparison between students who have FI cognitive style and students who have FD cognitive style."

Hypothesis 3, For the third hypothesis, $\mathrm{HO}$ is accepted and $\mathrm{H} 1$ is rejected at a significance level of 0.260 ( $P \geq 0.05 / 5 \%)$. Therefore, it 
can be stated that "there is no interactive influence between Learning Strategies and Cognitive Style on students' understanding of the concept of comparison."

Table 4. Scores of Posttest Results of Comparison Concept Understanding on Each Treatment Group

Descriptive Statistics

\begin{tabular}{llrrr}
\multicolumn{6}{l}{ Dependent Variable: POSTTEST } \\
\hline \hline MIETODE & KOGNITIF & Mean & 3td. Deviation & \multicolumn{1}{c}{ N } \\
\hline CP9 & FIELD INDEPENDENCE & 68.50 & 15.240 & 12 \\
& FIELD DEPENDENCE & 64.93 & 3.362 & 14 \\
& Total & 66.58 & 10.553 & 26 \\
\hline \multirow{2}{*}{ LCI } & FIELD INDEPENNDENCE & 70.33 & 10.325 & 12 \\
& FIELD DEPENDENCE & 61.07 & 3.173 & 15 \\
& Total & 65.19 & 8.517 & 27 \\
\hline Tolal & FIELD INDEPENDENCE & 69.42 & 12.705 & 24 \\
& FIELD DEPENDENCE & 62.93 & 3.760 & 29 \\
& Total & 65.87 & 9.503 & 53 \\
\hline
\end{tabular}

In Hypothesis 1, there is no difference in the learning outcomes of mathematics, namely the understanding of the concept of comparison between CPS and LCM learning strategies. However, based on the findings in Table 4, the calculation of the total average posttest score of the application of learning in this study shows the CPS learning strategy is better / higher than the average posttest score of the LCM learning strategy. Based on this finding, it can be concluded that the application of realistic mathematics with the cognitive style possessed by students (FI \& FD) is more suitable to be applied to the CPS learning strategy. Boud and Feletti (1997: 230) suggested that problem-based learning is the most significant innovation in education.

Unlike the findings of Sari, Suherman, Mirna (2014), based on the results of the hypothesis test analysis at the level of $\alpha=0.05$, obtained $\mathrm{P}$-value $=0.019$ and $\mathrm{P}$-value $<\alpha$, then $\mathrm{HO}$ is rejected and $\mathrm{H} 1$ is accepted, which means that the understanding of the mathematical concepts of students who take LCM is better than students who take conventional learning. In this regard, researchers are still limited to the understanding of the mathematical concepts.

In Hypothesis 2, table 4 shows that there are differences in the learning outcomes in understanding the concept of comparison between students who have $\mathrm{FI}$ cognitive style and students who have FD cognitive style in each class with different learning models, namely CPS and LCM model learning. The results of these tests indicate a different comprehension of the concept of comparison. Students with $\mathrm{Fl}$ cognitive style have better / higher scores than the students with FD cognitive style. Both are in the treatment of CPS and LCM learning strategies. Halini shows that students who have the FI cognitive style are suitable for the mathematical subject in the comparison chapter.

The results of Hypothesis 2 above support previous study by Rufi'i (2010). His study documented that the results of learning statistical concepts between students who have $\mathrm{FI}$ cognitive style and FD cognitive style showed a difference with $\mathrm{F}$-value $=4.994$ and $p$-value $=0.027<0.05$ so $\mathrm{HO}-2$ was rejected. This result also stated that students with $\mathrm{Fl}$ cognitive style have higher learning achievement of statistical concepts with a mean value 65,656 , which ranges from 63,192 to 68,120 with a standard error of 1,246 , compared to students having FD cognitive style with a mean value of 62,171 , which ranges from 60,318 to 64,023 with a standard error of 0.937.

Khafid (2013) argued in his research findings that students who have FI cognitive style have better learning outcomes (Geographic insight) than students who have FD cognitive style. His study also stated that students with $\mathrm{FI}$ cognitive style have the desire to succeed purely from within themselves, always work hard in competing with others and work independently and obtain achievements in accordance with the level of ability. According to Ulya (2015), from the results of the regression model, her study showed that the more students who have $\mathrm{Fl}$ cognitive style, the more increasing level of students' problem-solving abilities in mathematics subjects. In line with the above statement, Adnyani et al. (2013) presented descriptive data on the results of testing which showed that in achieving a decrease in misconceptions influenced by student characteristics having $\mathrm{FI}$ Cognitive Style. FI cognitive style tends to be higher in decreasing misconception compared to FD cognitive style, either taught with cognitive conflict strategy or conventional strategy. Resvirenol (2015) 
stated that there are significant differences in learning outcomes between students who have FI cognitive style and FD cognitive style, either on problem-based learning or direct learning, by showing the results of F-value of 107,616 and the value of $\alpha$ of $0,000(0,000<0,05)$.

In contrast to what was found by Sugiarso (2000), his study documented the difference in the initial learning strategy between Advance Organizer (AO) and Epitimo (E). It found that Epitimo Strategy is superior to Advance Organizer with a probability of $p$-value $=0.352$ $>0.05$, meaning that $\mathrm{HO}$ is accepted. However, there were no differences in learning outcomes of students who have FI Cognitive Style and FD Cognitive Style with $\mathrm{HO}$ accepted at a significant level of P > 0.05. Baiduri (2015) stated that the results of the different findings were based on the result of ANOVA $F(2.99)=0.764$ and significance $=0.468>0.05$ did not indicate a significant difference from the learning outcomes of mathematics between students who have FI, FD and FM (Field Mixed) Cognitive style. However, there are significant differences in the mathematics learning outcomes shown by male and female students who have FM Cognitive style.

In Table 4, the Results of Hypothesis 3 show no interaction between learning strategies and cognitive styles for the results of understanding the comparison concept. The type of interactions that occur includes ordinal interactions (Hair, 2010: 470) as in Figure 1 below:

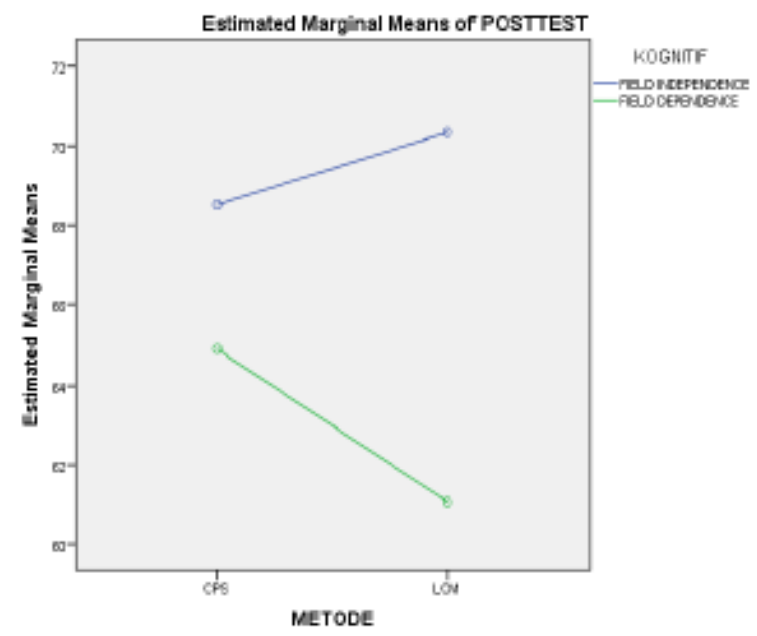

Figure 1. Graph of Interactive Influence Between Learning Strategies and Cognitive Style Against the Understanding of Comparison Concept

\section{CONCLUSION}

Based on the hypothesis testing conducted in this study, several conclusions can be stated as follows: there is no difference in the understanding of the concept of comparison in groups of students who take realistic mathematics learning through the Creative Problem Solving (CPS) and Learning Cycle Model (LCM) learning strategies.

There are differences in the understanding of the comparison concept between students who have FI Cognitive Style and students who have FD Cognitive Style. It is shown that students with FI Cognitive Style have better / higher learning outcomes in understanding the concept of comparison compared to students with FD Cognitive Style.

There is no interaction between learning strategies (Creative Problem Solving and Learning Cycle Model) and Cognitive Style (Field Independence and Field Dependence) towards the students' understanding of the concept of comparison.

\section{REFERENCES}

Adnyani, Sadia, Natajaya, (2013). Pengaruh Strategi Pembelajaran Konflik Kognitif Terhadap Penurunan Miskonsepsi Fisika Ditinjau dari Gaya Kognitif Siswa Kelas $X$ di SMA Negeri 1 Bebandem. (Online) https://journal.ac.id/index.php/cp/ article/view/1560 Diakses: 1 Desember 2017.

Baiduri, (2015). Gaya Kognitif dan Hasil Belajar Siswa Field Dependence-Independence. (online) https://media.neliti.com. publication Diakses: 31 Mei 2018.

Boud, D. \& Fellati, G.I., (1997). The Challenge of Problem Based Learning. London: Kogapage.

Catherine N. S., (2012). Prilaku Komunikasi Nonverbal Guru Dalam Kelas Pembelajaran: Maknanya Bagi Siswa SMA. (online). https://scholar.google. co.id. Diakses 2 Agustus 2018.

Degeng, I N. S., (1989). Teori Pembelajaran I: Taksonomi Variabel. Jakarta: Program Magister Manajemen Pendidikan Universitas Terbuka.

Degeng, I N. S., (2008). Pengembangan Model Pembelajaran, Teknologi Pembelajaran. 
Malang: Fakultas IImu Pendidikan IKIP Malang.

Degeng, I N. S., (2011). Mencari Paradigma Baru Pemecahan Masalah Belajar. Universitas PGRI Adi Bana.

Degeng, I N. S., (2013). Ilmu Pembelajaran. KlasifikasiVariabel untukPengembangan Teori dan Penelitian. Bandung: Aras Media.

Fogarty, R., (1997). Problem-Based-Learning and The Other Curriculum Models for Multiple Intelligences Classroom. Hawker Brownlow Education.

Hadi, (2017). Pendidikan Matematika Realistik. Jakarta: Rajawali Pers.

Haji, S., (2005). Pengaruh Pendekatan Matematika Realistik Terhadap Hasil Belajar Matematikadi Sekolah Dasar. Disertasi. PPs Unsuri Bandung. Tidak dipublikasikan.

Hisyam Z. dkk, (2008). Strategi Pembelajaran Aktif. Yogyakarta: Pustaka Insan Madani.

Khafid, (2013). Pengaruh Pembelajaran Berbasis Masalah dan Gaya Kognitif Terhadap Hasil Penanaman Wawasan Kegeografian. (Online) http://journal. um.ac.id/index.php/pendidkan-danpembelajaran/article/view/4394 Diakses: 1 Desember 2017.

Madiya,(2012). Pengaruh Model Pembelajaran Berbasis Masalah Terhadap Prestasi Belajar Kimia dan Konsep Diri Siswa SMA Ditinjau dari Gaya Kognitif. (Online) http://pascha.undiksha.ac.id/e-journal/ index.php/jurnal_ipa/article/view/477 Diakses: 1 Desember 2017.

Mukhlason, Degeng, I N. S.,\& Sihkabuden, (2015). Pengaruh Strategi Pembelajaran (Peta Konsep dan Rangkuman) dan Motivasi Berprestasi Terhadap Hasil Belajar Pembelajaran Sejarah. (online). https://scholar.google.co.id. Diakses 26 Juli 2018.

Nurbani D., Gusrayani D., Jayadinata A. K., (2016). Pengaruh Model Learning Cycle Terhadap Keterampilan Proses Sains Siswa SD Kelas IV pada Materi Hubungan Antara Sifat Bahan Dengan Kegunaannya. (online). https://scholar. google.co.id. Diakses 2 Agustus 2018.
Pranandari I. K., Degeng, I N. S.,\& Fattah H., (2016). Korelasi Antara Persepsi Siswa Tentang Pengelola Kelas, Hubungan Teman Sebaya (PEER RELATIONSHIP), dan Hasil Belajar Siswa Kelas IV SD Negeri Kecamatan Sanawetan Kota Blitar. (online). https://scholar.google. co.id. Diakses 2 Agustus 2018.

Resvirenol, (2015). Pengaruh Strategi Pembelajaran Berbasis Masalah Terhadap Hasil Belajar Mahasiswa yang Memiliki Gaya Kognitif Berbeda. (Online) http://jurnal.119.252.161.254/ e-journal/index.php/jurnal_ap/article/ view/956 Diakses: 1 Desember 2017.

Rufi'i, (2010). Pengaruh Strategi Pembelajaran dan Gaya Kognitif Terhadap Perolehan Belajar Konsep dan Prosedur Statstik. Disertasi tidak diterbitkan. Malang: PPSJ Teknologi Pembelajaran Universitas Negeri Malang.

Santoso, (2005). Metodelogi Penenlitian Kuantitatif dan Kualitatif. Jakarta: Prestasi Pustaka.

Sari, Suherman, Mirna. 2014. Pengaruh Model Pembelajaran Learning Cycle Terhadap Pemahaman Konsep Matematika Siswa Kelas X SMA Negeri 15 Padang Tahun Pelajaran 2013/2014. (Online) https:// scholar.google.co.id/scholar?statr $=10$ $\& q=$ matematika+realistik\&hl=en\&has_ sdt=0,5 Diakses: 1 Desember 2017.

Shiomin, A. (2014). 68 Model Pembelajaran Inovatif Dalam Kurikulum 2013. Yogyakarta: Ar-Ruzz Media.

Soviawati, (2011). Pendekatan Matematika Realistik (PMR) untuk Meningkatkan Kemampuan Berfikir Siswa ditingkat Sekolah Dasar. (Online) https://scholar. google.co.id/scholar?statr $=10 \& q=$ mat ematika+realistik\&hl=en\&has_sdt $=0,5$ Diakses: 1 Desember 2017.

Sudirman, N. dkk, (1992). Ilmu Pendidikan. Bandung: Remaja Rosdakarya Offset.

Sutinah, Degeng, I N. S.,\& Akbar, S., (2008). Model Pembelajaran Kooperatif Tipe Students Team Achievment. (online). (ejournal.um.ac.id) Diakses 26 Juli 2018.

Stenberg, R. J. dan Elena L. G., (1997). Are Cognetive Style Stiil in Style?. American 
Psychologist Association, Volume 52, No. 7. Hal 700-712

Ulya, (2015). Hubungan Gaya Kognitif Dengan Kemampuan Pemecahan Masalah Matematika Siswa. (Online) jurnal.umk.
ac.id.article.viewFile Diakses: 31 Mei 2018.

Widodo, A., Wuryastuti, S. \& Margaretha. (2010). Pendidikan IPA di Sekolah Dasar. Bandung: UPI Press. 